Bangladesh J.Bot. 42(2): 301-306, 2013 (December)

\title{
EFFECTS OF LEAF AND PLANT AGE ON SPECIFIC LEAF AREA IN DECIDUOUS TREE SPECIES QUERCUS CERRIS L. VAR. CERRIS
}

\author{
Neslihan Karavin* \\ Department of Biology, Faculty of Arts and Science, Amasya University, Amasya, Turkey
}

Key words: Plant age, Specific leaf area, Deciduous, Oak

\begin{abstract}
In Quercus cerris L. var. cerris, four diameters at breast height (BDH) groups were selected as a surrogate for approximate plant age groups to study the effects of plant and leaf age on leaf dry mass, leaf area and specific leaf area. The forms of fluctuations in specific leaf area (SLA) of all DBH groups were similar during the growth period. The minimum SLA was calculated at the leaves' mature phase. Leaf area did not differ significantly according to leaf age. Significant differences caused by leaf age were determined in mean leaf dry mass and SLA. No significant differences in mean SLA caused by plant age were found. Leaf area and leaf dry mass significantly varied among DBH groups. Leaf area was positively correlated with leaf dry mass, and SLA was negatively correlated with leaf dry mass, while there was no significant relationship with leaf area.
\end{abstract}

\section{Introduction}

Specific leaf area (SLA) is a fundamental parameter for plant growth, denoting leaf surface area per unit mass. SLA reflects the photosynthetic capacities of plant species and characterizes plants' adaptation to the environment. For these reasons, SLA is widely used as a key factor in various ecological studies on photosynthesis, respiration, biomass, resource use and growth strategies of plant species (Reich et al. 1991, Wilson et al. 1999, Li et al. 2005, Liu et al. 2008). Genetic features constrain the limits of SLA for individual species (White and Scott 2006), but various environmental factors may affect the SLA of individual plants, such as light regime, water supply, nutrient uptake. Additionally, not only environmental factors but also plant status may have an effect on SLA, (e.g. ontogenetic factors like leaf and plant age). There are many reports about the role of leaf and plant age in affecting leaf traits, especially SLA. These reports are generally concerned with crop plants or evergreens, especially with Eucalyptus (Biemond et al. 1995, Bertin and Gary 1998, Li et al. 1999, Day et al. 2001, England and Attiwill 2006, Jullien et al. 2009, Nouvellon et al. 2010). Previous studies reported that SLA decreased with increased leaf age (Reich et al. 1991, Luo et al. 2005, Milla et al. 2008) and similarly, decreased with increased plant age or size (Greenwood et al. 2008, Liu et al. 2010, Nouvellon et al. 2010). However, in the studies of Day et al. (2001) and Vanderklein et al. (2007), SLA did not change with increasing plant age.

This subject is especially important for ecological and physiological studies, yet scientists cannot completely explain it. In order to reach a consensus about the effect of leaf and plant age on SLA, more studies on various plant species and in different regions are required. In this paper, whether the specific leaf area of a deciduous oak varies due to leaf and plant age has been studied. According to general trends observed for deciduous species (Poorter et al. 2009), the expectations were that increased plant age would lead to decreased SLA and increased leaf age would not lead to any variation in SLA. For this purpose, Quercus cerris L. var. cerris (also called hairy oak or Turkey oak) individuals was chosen as study material. This oak is a deciduous tree native to southern Europe and Asia Minor and a widespread characteristic species in the study area.

*Author for correspondence: <nnecli@gmail.com>. 


\section{Materials and Methods}

The study area is a Quercus cerris L. var. cerris woodland in northern Turkey (4121.982'N, $\left.36^{\circ} 11.152^{\prime} \mathrm{E}\right)$. Canopy cover of the area is $45 \%$ and tree density is about 85 per hectare. Mean altitude of the study area is 300 MSL. The soil of the study area is grey-brown and podzolic. Because of the precipitation in the area, the colour of the upper horizon (A) and the deep layers of these soils are grey and brown, respectively (Özen and Kılınç 1988). Mediterranean climate is dominant in the study area. The annual mean temperature is $14.2^{\circ} \mathrm{C}$, while maximum temperature is $37.4^{\circ} \mathrm{C}$, and minimum temperature is $-7.0^{\circ} \mathrm{C}$. Total annual precipitation is $668.9 \mathrm{~mm}^{3}$.

Diameter at breast height (DBH) of trees as a surrogate was used for approximate tree age (Day et al. 2001). Differences in DBH among close range trees growing in the same habitat provide rough information about tree age. Four oak individuals which had similar DBH for each group were selected (mean DBH for group 1: $101.92 \mathrm{~mm}$, group 2: $165.60 \mathrm{~mm}$, group 3: 229.30 $\mathrm{mm}$, group 4: $292.98 \mathrm{~mm}$ ). Differences among groups were tested with one-way ANOVA and it was determined that DBH groups were significantly different (Table 1). In order to minimize variability among and within trees caused by light, tree species were selected from an open area in the border of the forest, and leaf samples were collected from an outer location of the tree crown. Montly leaf samples from equal positions (direction, height, branch, etc.) for all of trees were collected from May (beginning of the growth period) to November 2010 (senescence phase). A lateral branch which was unshaded from each tree was selected and marked and leaf samples were always collected from the same branch. Twenty undamaged leaves among the leaves collected from each specimen were singled out. In order to determine leaf dry mass, the leaf samples were cleaned and then put into a drying oven at $70^{\circ} \mathrm{C}$ until the leaves reached a constant height. Leaf samples were weighed and their dry masses were determined. LI-COR portable leaf area meter were used to determine mean leaf areas of the leaf samples. The SLA $\left(\mathrm{mm}^{2} / \mathrm{mg}\right)$ values of each groups were calculated by dividing mean leaf area $\left(\mathrm{mm}^{2}\right)$ with mean leaf dry mass (mg).

Mean leaf dry mass, leaf area and SLA were calculated for each age group and month. Analyses were performed using SPSS 15.0 for Windows at the significance level of $p<0.05$. The effect of plant and leaf age on leaf area, leaf dry mass, SLA were tested by two-way full-factorial analysis of variance (ANOVA). Differences in leaf area, leaf dry mass, SLA among months and DBH groups were analyzed separately by independent-samples for $\mathrm{T}$ test. Means were separated by Tukey's Studentized Range (HSD) test, and homogeneity of variances was assessed by Levine's test. Correlations between leaf area, leaf dry mass and SLA were determined by Pearson correlation coefficient (2-tailed).

\section{Results and Discussion}

Mean leaf area, leaf dry mass and SLA values of DBH groups are given by month in Table 1 . For Q. cerris var. cerris, forms of fluctuations in SLA of all DBH groups were similar during the growth period. Mean SLA fluctuations of DBH groups across growth period were shown in Fig. 1. Group 3 exhibited maximum SLA peak among DBH groups $\left(1.48 \mathrm{~mm}^{2} / \mathrm{mg}\right)$, followed by group 4 $\left(1.47 \mathrm{~mm}^{2} / \mathrm{mg}\right)$, group $1\left(1.43 \mathrm{~mm}^{2} / \mathrm{mg}\right)$ and group $2\left(1.38 \mathrm{~mm}^{2} / \mathrm{mg}\right)$.

Leaf area of each DBH group did not differ significantly according to leaf age. Leaf dry mass changed significantly with leaf age in group 1 and unchanged in other groups. SLA significantly differed according to leaf age in group 1 and group 4. Leaf area and leaf dry mass significantly varied among DBH groups in May and July, and May and September, respectively. SLA didn't significantly varied among DBH groups. However, when the data were tested totally, it was found that leaf age affected leaf dry mass and SLA, and plant age affected leaf area and leaf dry mass. Leaf age and plant age together did not significantly affect leaf area, leaf dry mass and SLA (Table 
2). There was a positive correlation between leaf area and leaf dry mass, and there was a negative correlation between leaf dry mass and SLA (Table 3).

Table 1. Mean ( \pm SE) leaf area, leaf dry mass and SLA in different months and DBH groups.

\begin{tabular}{|c|c|c|c|c|c|}
\hline & \multicolumn{5}{|c|}{ Leaf area $\left(\mathrm{mm}^{2}\right)$} \\
\hline Months & Group $1(\mathrm{~N}=4)$ & Group $2(\mathrm{~N}=4)$ & Group $3(\mathrm{~N}=4)$ & Group $4(\mathrm{~N}=4)$ & Total $(\mathrm{N}=16)$ \\
\hline May & $5.582 \pm 0.317 \mathrm{ABa}$ & $4.716 \pm 0.190 \mathrm{Aa}$ & $5.840 \pm 0.279 \mathrm{Ba}$ & $6.842 \pm 1.102 \mathrm{ABa}$ & $5.745 \pm 0.331 \mathrm{a}$ \\
\hline June & $5.723 \pm 0.561 \mathrm{Aa}$ & $5.079 \pm 0.051 \mathrm{Aa}$ & $5.862 \pm 0.564 \mathrm{Aa}$ & $6.544 \pm 0.798$ Аа & $5.802 \pm 0.286 \mathrm{a}$ \\
\hline July & $5.227 \pm 0.535 \mathrm{ABa}$ & $5.168 \pm 0.160$ Аа & $6.193 \pm 0.321 \mathrm{Ba}$ & $5.464 \pm 0.688 \mathrm{ABa}$ & $5.513 \pm 0.236 \mathrm{a}$ \\
\hline Aug. & $5.406 \pm 0.533 \mathrm{Aа}$ & $4.907 \pm 0.254 \mathrm{Aa}$ & $5.956 \pm 0.443 \mathrm{Aa}$ & $6.125 \pm 0.807$ Аа & $5.598 \pm 0.274 \mathrm{a}$ \\
\hline Sept. & $5.713 \pm 0.549 \mathrm{Aa}$ & $4.870 \pm 0.330 \mathrm{Aa}$ & $5.654 \pm 0.562 \mathrm{Aa}$ & $6.478 \pm 0.910 \mathrm{Aa}$ & $5.679 \pm 0.315 a$ \\
\hline Oct. & $5.730 \pm 0.394 \mathrm{Aa}$ & $5.439 \pm 0.285$ Аа & $6.593 \pm 0.643 \mathrm{Aа}$ & $6.470 \pm 0.977$ Аа & $6.058 \pm 0.310 \mathrm{a}$ \\
\hline Nov. & $5.207 \pm 0.782 \mathrm{Aa}$ & $4.821 \pm 0.544 \mathrm{Aa}$ & $5.370 \pm 0.629 \mathrm{Aa}$ & $5.881 \pm 0.661$ Аа & $5.320 \pm 0.311 \mathrm{a}$ \\
\hline \multirow[t]{2}{*}{ Total } & $5.512 \pm 0.185 \mathrm{AB}$ & $5.000 \pm 0.108 \mathrm{~A}$ & $5.924 \pm 0.184 \mathrm{~B}$ & $6.258 \pm 0.299 \mathrm{~B}$ & \\
\hline & \multicolumn{5}{|c|}{ Leaf dry mass (mg) } \\
\hline May & $4.082 \pm 0.271 \mathrm{ABa}$ & $3.625 \pm 0.342 \mathrm{Aa}$ & $4.043 \pm 0.464 \mathrm{ABa}$ & $4.748 \pm 0.300 \mathrm{Ba}$ & $4.124 \pm 0.189 \mathrm{ab}$ \\
\hline June & $5.098 \pm 0.607$ Aabc & $4.125 \pm 0.292 \mathrm{Aa}$ & $5.263 \pm 0.628 \mathrm{Aa}$ & $5.470 \pm 0.552 \mathrm{Aa}$ & $4.989 \pm 0.275 \mathrm{ab}$ \\
\hline July & $4.429 \pm 0.466$ Aabc & $4.267 \pm 0.378 \mathrm{Aa}$ & $5.071 \pm 0.449 \mathrm{Aa}$ & $4.470 \pm 0.562 \mathrm{Aa}$ & $4.559 \pm 0.224 \mathrm{ab}$ \\
\hline Aug. & $4.712 \pm 0.553$ Aabc & $4.686 \pm 0.649 \mathrm{Aa}$ & $5.283 \pm 0.744 \mathrm{Aa}$ & $5.138 \pm 0.425$ Аа & $4.955 \pm 0.279 a b$ \\
\hline Sept. & $5.942 \pm 0.507 \mathrm{ACb}$ & $4.272 \pm 0.326 \mathrm{Ba}$ & $5.197 \pm 0.841 \mathrm{ABCa}$ & $5.855 \pm 0.472 \mathrm{Ca}$ & $5.316 \pm 0.307 \mathrm{a}$ \\
\hline Oct. & $4.249 \pm 0.541$ Aabc & $4.383 \pm 0.496$ Аа & $5.870 \pm 1.233$ Аа & $4.784 \pm 0.775$ Аа & $4.821 \pm 0.400 \mathrm{ab}$ \\
\hline Nov. & $3.731 \pm 0.734$ Ac & $3.526 \pm 0.434 \mathrm{Aa}$ & $3.888 \pm 0.374 \mathrm{Aa}$ & $4.094 \pm 0.642 \mathrm{Aa}$ & $3.810 \pm 0.258 b$ \\
\hline \multirow[t]{2}{*}{ Total } & $4.606 \pm 0.223 \mathrm{AB}$ & $4.126 \pm 0.162 \mathrm{~A}$ & $4.945 \pm 0.275 \mathrm{~B}$ & $4.937 \pm 0.213 \mathrm{~B}$ & \\
\hline & \multicolumn{5}{|c|}{$\mathrm{SLA}\left(\mathrm{mm}^{2} / \mathrm{mg}\right)$} \\
\hline May & $1.373 \pm 0.049$ Aade & $1.331 \pm 0.114 \mathrm{Aa}$ & $1.485 \pm 0.119 \mathrm{Aa}$ & $1.440 \pm 0.209$ Aabc & $1.407 \pm 0.063 \mathrm{bc}$ \\
\hline June & $1.143 \pm 0.095$ Aabcde & $1.249 \pm 0.084 \mathrm{Aa}$ & $1.122 \pm 0.024 \mathrm{Aa}$ & $1.207 \pm 0.125$ Aabc & $1.180 \pm 0.042 \mathrm{ab}$ \\
\hline July & $1.217 \pm 0.190$ Aabcde & $1.239 \pm 0.113 \mathrm{Aa}$ & $1.233 \pm 0.045 \mathrm{Aa}$ & $1.249 \pm 0.161$ Aabc & $1.235 \pm 0.062 \mathrm{abc}$ \\
\hline Aug. & $1.160 \pm 0.059$ Abcd & $1.091 \pm 0.107 \mathrm{Aa}$ & $1.169 \pm 0.101 \mathrm{Aa}$ & $1.178 \pm 0.063 \mathrm{Aab}$ & $1.150 \pm 0.039 \mathrm{a}$ \\
\hline Sept. & $0.973 \pm 0.089$ Abc & $1.154 \pm 0.098 \mathrm{Aa}$ & $1.130 \pm 0.090 \mathrm{Aa}$ & $1.101 \pm 0.096 \mathrm{Aab}$ & $1.090 \pm 0.046 \mathrm{a}$ \\
\hline Oct. & $1.386 \pm 0.111$ Aabde & $1.276 \pm 0.118 \mathrm{Aa}$ & $1.213 \pm 0.150 \mathrm{Aa}$ & $1.381 \pm 0.113$ Aabc & $1.314 \pm 0.059 \mathrm{abc}$ \\
\hline Nov. & $1.433 \pm 0.075$ Aabde & $1.376 \pm 0.061 \mathrm{Aa}$ & $1.377 \pm 0.096 \mathrm{Aа}$ & $1.466 \pm 0.078 \mathrm{Ac}$ & $1.413 \pm 0.037 \mathrm{c}$ \\
\hline Total & $1.241 \pm 0.046 \mathrm{~A}$ & $1.245 \pm 0.038 \mathrm{~A}$ & $1.247 \pm 0.041 \mathrm{~A}$ & $1.289 \pm 0.050 \mathrm{~A}$ & \\
\hline
\end{tabular}

Small letters indicate differences among months and capital letters indicate differences among DBH groups. Means followed by different letters differ significantly $(\mathrm{p}<0.05)$.

The study showed that monthly fluctuations in SLA of all DBH groups were similar during the growth period for Q. cerris var. cerris. According to Poorter et al. (2009), "SLA is low right after bud-burst and increases rapidly during leaf expansion, after which there is a decrease again (Jurik 1986), presumably because of a build-up of cell wall material and chloroplasts. After first 30 days, SLA remains remarkably constant in most trees, until the onset of senescence when SLA increases again." In unfavourable conditions, trees resorb nutrients from leaves to the durable organs such as shoots, stems, and roots before they defoliate, and this mechanism is called nutrient resorption (Chapin 1980, Rejmánková 2005). Hence, as a result of nutrient resorption, leaf mass decreases and SLA of leaves rise during senescence. 


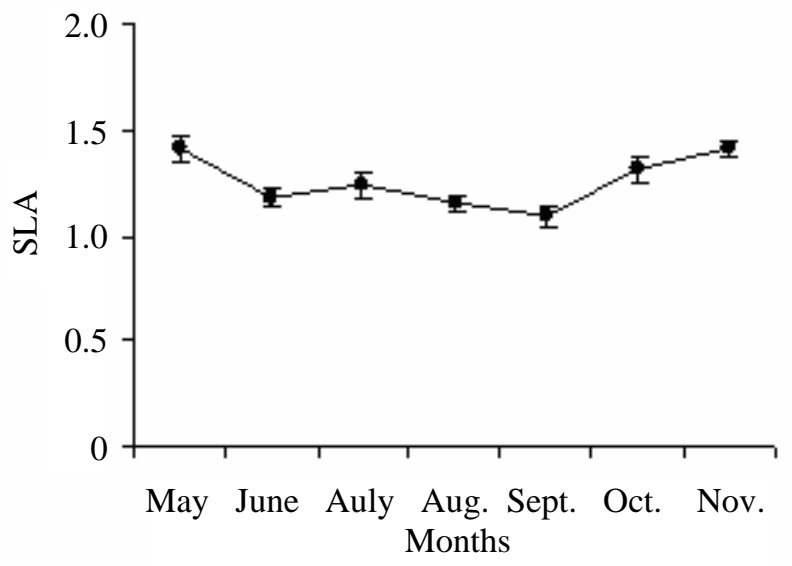

Fig. 1. Mean ( \pm SE) SLA $\left(\mathrm{mm}^{2} / \mathrm{mg}\right)$ fluctuations of DBH groups across growth period.

Table 2. Two-way full-factorial ANOVA table of differences in leaf area, dry mass and SLA due to leaf and DBH groups.

\begin{tabular}{lllllll}
\hline \multirow{2}{*}{ Source } & $\begin{array}{l}\text { Dependent } \\
\text { variable }\end{array}$ & $\begin{array}{l}\text { Type III } \\
\text { sum of } \\
\text { squares }\end{array}$ & Df & $\begin{array}{l}\text { Mean } \\
\text { square }\end{array}$ & F & Sig. \\
\hline \multirow{2}{*}{ DBH groups } & Leaf area & 24.737 & 3 & 8.246 & 5.962 & $\mathbf{0 . 0 0 1}$ \\
& Leaf dry mass & 12.478 & 3 & 4.159 & 3.159 & $\mathbf{0 . 0 2 9}$ \\
& SLA & 0.042 & 3 & 0.014 & 0.296 & 0.828 \\
& Leaf area & 5.216 & 6 & 0.869 & 0.629 & 0.707 \\
Leaf age & Leaf dry mass & 26.751 & 6 & 4.458 & 3.387 & $\mathbf{0 . 0 0 5}$ \\
DBH groups $\times$ leaf age & SLA & 1.538 & 6 & 0.256 & 5.404 & $\mathbf{0 . 0 0 0}$ \\
& Leaf area & 6.408 & 18 & 0.356 & 0.257 & 0.999 \\
& Leaf dry mass & 11.268 & 18 & 0.626 & 0.475 & 0.962 \\
\hline
\end{tabular}

Differences are significant at the $\mathrm{P}<0.05$ level.

There were significant variations in leaf dry mass and SLA caused by leaf age for $Q$. cerris var. cerris. SLA trends of $Q$. cerris var. cerris during the growing period nearly concurred with that of temperate deciduous trees in the review of Poorter et al. (2009) and Nouvellon et al. (2010). Fluctuations in leaf dry mass and SLA squared with seasons, which affect photosynthesis. Age-dependent decreases in SLA are associated with leaf density and thickness (Milla et al. 2008, Poorter et al. 2009). Accumulation of carbon-rich chemicals and production of secondary vascular bundles and sclerenchyma decrease leaf density. Increasing numbers of spongy or palisade mesophyll layers leads to a rise in leaf thickness. Increasing leaf density and thickness increases leaf dry mass, and decreases SLA. In Q. cerris var. cerris, SLA fluctuated and did not decrease consistently across the growth period. However, it decreased until the beginning of the senescence period and then increased due to nutrient resorption. It is quite possible to examine decreasing SLA in long-lived evergreens, because the mature period of leaves of evergreen species is longer than deciduous species. Nevertheless, in deciduous trees, such as $Q$. cerris var. cerris, the leaf 
lifespan is shorter, so they have little time for producing leaves, flowers and acorns. Their leaves are thinner than evergreens and their leaf density is lower than evergreens. Thus, differences in SLA caused by leaf age are much clearer in evergreen species than in deciduous species.

Table 3. Pearson correlation coefficient among leaf area, leaf dry mass and SLA.

\begin{tabular}{lllc}
\hline & & Leaf dry mass & SLA \\
\hline Leaf area & Pearson correlation & $0.678^{*}$ & 0.134 \\
& Sig. (2-tailed) & 0.000 & 0.159 \\
& $\mathrm{~N}$ & 112 & 112 \\
Leaf dry mass & Pearson correlation & 1 & $-0.617^{*}$ \\
& Sig. (2-tailed) & & 0.000 \\
& $\mathrm{~N}$ & 112 & 112 \\
\hline
\end{tabular}

* Correlation is significant at the 0.05 level (2-tailed).

Several studies indicated that SLA decreased with plant age or size (Greenwood et al. 2008, Liu et al. 2010, Nouvellon et al. 2010). According to Nouvellon et al. (2010), England and Attiwill (2006) suggested that the observed decreases in SLA with increasing tree age and height may result from (1) increasing leaf water stress (more negative water potential), due to gravity and/or increased path length resistance; and (2) a hypothetical age effect, i.e., some inherent genetic factor that slows growth of older trees, thereby reducing carbon demand, which reduces carbon export from the leaves, and therefore increases dry mass accumulation in the leaf". However, in the study of Day et al. (2001), differences in SLA, which showed a declining trend with scion donor age, were not significant, and in Vanderklein et al. (2007), SLA showed no change with increasing donor-tree age. Similarly, differences in SLA, which increased with plant age among DBH groups, were not significant. On the other hand, leaf area and leaf dry mass changed significantly among DBH groups, and increased with plant age. These correlations may be caused by several factors. One may be differences in response of life forms or plant species. Factors controlling age-related trends may vary among species and life stages within species (e.g. between rapidly growing, short-lived species and slowly growing, long-lived species or between juvenile stage and adult stage) (Day et al. 2002). Thus, growth forms may vary in response to time effects on leaf traits, because of differences in their leaf longevity and life form. Second, resource, light and water status of the area may play a role in age-related responses (Greenwood et al. 2008). A positive correlation was found between leaf area and leaf dry mass. This means that dry mass increased in parallel with leaf expansion. Additionally, SLA was negatively correlated with leaf dry mass while it had no significant relationship with leaf area. This means that SLA was closely related to biomass accumulation in leaves and may be affected indirectly by factors which play a role in the production of biomass. Similar to the present study, Liu et al. (2008) determined a positive correlation between leaf area and leaf dry mass and a negative correlation between leaf dry mass and SLA.

In brief, results of the present study showed that leaf age affected SLA, and there was no significant relationship between plant age and SLA for Q. cerris var. cerris. Additionally, correlations determined between leaf area and leaf dry mass, and between leaf dry mass and SLA confirmed previous findings.

\section{References}

Bertin N and Gary C 1998. Short and long term fluctuations of the leaf mass per area of tomato plants implications for growth models. Annals Bot. 82: 71-81. 
Biemond H, Vos J and Struik PC 1995. Effects of nitrogen on development and growth of the leaves of vegetables. 1. Appearance, expansion growth and life span of leaves of Brussels sprouts plants. Netherlands J. Agric. Sci. 43: 217-232.

Chapin FS III 1980. The mineral nutrition of wild plants. Ann. Rev. Ecol. Syst. 11: 233-260.

Day ME, Greenwood MG and White AS 2001. Age-related changes in foliar morphology and physiology in red spruce and their influence on declining photosynthetic rates and productivity with tree age. Tree Physiol. 21: 1195-1204.

Day ME, Greenwood MG and Diaz-Sala C 2002. Age- and size-related trends in woody plant shoot development regulatory pathways and evidence for genetic control. Tree Physiol. 22: 507-513.

England JR and Attiwill PM 2006. Changes in leaf morphology and anatomy with tree age and height in the broadleaved evergreen species, Eucalyptus regnans F. Muell. Trees 20: 79-90.

Greenwood MS, Ward MH, Day ME, Adams SL and Bond BJ 2008. Age-related trends in red spruce foliar plasticity in relation to declining productivity. Tree Physiol. 28: 225-232.

Jullien A, Allirand JM, Mathieu A, Andrieu B and Ney B 2009. Variations in leaf mass per area according to $\mathrm{N}$ nutrition, plant age, and leaf position reflect ontogenetic plasticity in winter oilseed rape Brassica napus L.. Field Crops Res. 114: 188-197.

Jurick TW 1986. Temporal and spatial patterns of specific leaf weight in successional northern hardwood tree species. Amer. J. Bot. 73: 1083-1092.

Li B, Suzuki JI and Hara T 1999. Competitive ability of two Brassica varieties in relation to biomass allocation and morphological plasticity under varying nutrient availability. Ecol. Res. 14: 255-266.

Li Y, Johnson DA, SuY, Cui J and Zhang T 2005. Specific leaf area and leaf dry matter content of plants growing in sand dunes. Bot. Bull. Acad. Sinica 46: 127-134.

Liu J, Zeng D, Lee DK, Fan Z and Zhong L 2008. Leaf traits and their interrelationship of 23 plant species in southeast of Keerqin Sandy Lands, China. Front. Biol. China 3: 332-337.

Liu F, Yang W, Wang Z, Xu Z, Liu H, Zhang M, Liu Y, An S and Sun S 2010. Plant size effects on the relationships among specific leaf area, leaf nutrient content, and photosynthetic capacity in tropical woody species. Acta Oecologica 36: 149-159.

Luo T, Luo J and Pan Y 2005. Leaf traits and associated ecosystem characteristics across subtropical and timberline forests in the Gongga mountains, eastern Tibetan plateau. Oecologia 142: 261-273.

Milla R, Reich PB, Niinemets Ü and Castro-Diez P 2008. Environmental and developmental controls on specific leaf area are little modified by leaf allometry. Functional Ecol. 22: 565-576.

Nouvellon Y, Laclau JP, Epron D, Kinana A, Mabiala A, Roupsard O, Bonnefond JM, Le Maire G, Marsden C, Bontemps JD and Saint-Andre' L 2010. Within-stand and seasonal variations of specific leaf area in a clonal Eucalyptus plantation in the Republic of Congo. Forest Ecol. Management 259: 1796-1807.

Özen F and Kılınç M 1988. A phytosociological study on the vegetation of Ondokuz Mayıs University Kurupelit campus area and its surroundings. In IX. Nat. Biol. Congr. Booklet Sivas, Turkey, 463-472.

Poorter H, Niinemets Ü, Poorter I, Wright IJ and Villar R 2009. Causes and consequences of variation in leaf mass per area LMA a meta-analysis. New Phytol. 182: 565-588.

Reich PB, Walters MB and Ellsworth DS 1991. Leaf age and season influence the relationships between leaf nitrogen, leaf mass per area and photosynthesis in maple and oak trees. Plant, Cell and Environ. 14: 251259.

Rejmánková E 2005. Nutrient resorption in wetland macrophytes comparison across several regions of different nutrient status. New Phytol. 167: 471-482.

Vanderklein D, Martinez-Vilalta J, Lee S and Mencuccini M 2007. Plant size, not age, regulates growth and gas exchange in grafted Scots pine trees. Tree Physiol. 27: 71-79.

White JD and Scott NA 2006. Specific leaf area and nitrogen distribution in New Zealand forests Species independently respond to intercepted light. Forest Ecol. Management 226: 319-329.

Wilson PJ, Thompson K and Hodgson JG 1999. Specific leaf area and leaf dry matter content as alternative predictors of plant strategies. New Phytol. 143: 155-162.

(Manuscript received on 20 March, 2012; revised on 25 August, 2013 